\title{
Assessment of Microbial Load of Un-pasteurized Fruit Juices and in vitro Antibacterial Potential of Honey Against Bacterial Isolates
}

\author{
Muhammad Naeem Iqbal ${ }^{1,2,4, *}$, Aftab Ahmad Anjum², Muhammad Asad Ali ${ }^{2}$, Firasat Hussain ${ }^{2}$, \\ Shahzad $\mathrm{Ali}^{3}$, Ali Muhammad ${ }^{4}$, Muhammad Irfan ${ }^{4}$, Aftab Ahmad ${ }^{5}$, Muhammad Irfan $^{6}$ and \\ Asghar Shabbir ${ }^{7}$
}

\begin{abstract}
${ }^{I}$ The School of Life Sciences, Fujian Agriculture and Forestry University, Fuzhou 350002, China, ${ }^{2}$ Department of Microbiology, ${ }^{3}$ Department of Wildlife and Ecology, University of Veterinary and Animal Sciences, Lahore 54000, Pakistan; ${ }^{4}$ Department of Zoology, PMAS Arid Agriculture University, Rawalpindi 46000, Pakistan; ${ }^{5}$ National Academy of Young Scientists (NAYS), ${ }^{6}$ Department of Zoology, University of the Punjab, Lahore 54000, Pakistan; ${ }^{7}$ COMSATS Institute of Information Technology, Islamabad 44000, Pakistan
\end{abstract}

\begin{abstract}
The development of resistance in bacteria against commonly used antibiotics/drugs is of considerable medical significance. Aim of this study was to determine the microbial load of un-pasteurized packed fruit juices sold in Lahore city and to determine antibacterial activity of five different honey samples against isolated bacteria. Unpasteurized fruit juice samples $(n=60)$ were collected from street vendors. All the samples were subjected to Total viable count (TVC), Staphylococcal count (SC) and Coliform count (CC). One hundred and ten strains of bacteria were isolated from various fruit juices and identified on the basis of cultural characters, morphology and biochemical characters. Mean TVCs, SCs and CCs of juices $(6.80 \pm 1.91,5.45 \pm 1.06$ and $3.25 \pm 1.25 \log 10 \mathrm{CFU} / \mathrm{ml}$ respectively) were non-significant with standard permissible limits $(\mathrm{p}<0.05)$. Among all the fruit juices, $66.66 \%$ of samples had TVC more than $4 \log 10 \mathrm{CFU} / \mathrm{ml}, 51.66 \%$ of samples had SC more than $3 \log 10 \mathrm{CFU} / \mathrm{ml}$ and $46.66 \%$ of samples had CC more than $2 \log 10 \mathrm{CFU} / \mathrm{ml}$. Among the bacillus isolates purified, were Bacillus alvei, Bacillus subtilis, Bacillus polymyxa, Pseudomonas aeruginosa, Staphylococcus aureus, Klebsiella pneumonia, Escherichia coli and Enterobecter. All five different types of honey samples used in this study showed antibacterial activity against $B$. alvei, B. polymyxa, B. subtilis and $S$. aureus and no activity against $P$. aeruginosa, K. pneumonia, Enterobecter and E. coli. It is concluded that microbial load in unpasteurized fruit juices is significantly higher than standard permissible limits which insinuates its possible role in spoilage and food borne illnesses. Periodic monitoring of packed fruit juices should be carried out to make them safe for consumption. Honey can be used as an alternative for treatment of various infections, especially those caused by antibiotic resistant bacteria.
\end{abstract}

Keywords: Antibacterial activity, contamination, honey, hygienic quality, microorganism, Unpasteurized fruit juices.

\section{INTRODUCTION}

Juice is the aqueous liquid, purée of the edible portions, or any concentrates of such liquid or puree from one or more fruits or vegetables [1]. Fruit juices are used for their nutritional value, refreshing nature and for their medicinal importance [2]. Fruit and vegetable juices play role in detoxification of human body and also have a great role in improvement of blood lipid profile in patients of hypercholesterolemia [3]. These juices are used unpasteurized in routine [4-6]. Unpasteurized juices prepared by street vendors are more appealing for consumers due to its fresh flavor [7].

Pathogenic microbes may enter in fruits during their growth and harvesting through damaged surfaces and punctures. Juices may be contaminated with microbes from raw material, juice machine, handler and unhygienic conditions [8]. Huge bacterial load of total coliform, faecal coliform,

*Address correspondence to this author at the The School of Life Sciences, Fujian Agriculture and Forestry University Fuzhou, China;

Tels: +92-3328894212, +8618905904394;

E-mail: driqbalnaeem@hotmail.com
Staphylococcal spp. and Salmonella may be present in fresh street vended fruit juices. The main microbial contaminants in fruit juices are Staphylococcus aureus, E. coli, Kebsiella, Vibrio cholera, Streptococcal spp. and Candida albicans [9]. Other common bacterial contaminants of fruit juices are Pseudomonas aerogenosa, Proteus spp. and Salmonella typhi.

Antibiotic-resistant bacteria are causing a great damage to public health. The number of new antibiotics being developed is limited compared to increasing frequencies of bacterial resistance. The need of the hour is to develop alternative antimicrobial strategies. The presence of cenamic acid, antioxidant agent and flavonoids is responsible for antibacterial potential of honey [10]. Honey has been used to treat infections since ancient Egyptians and Greeks, but only recently scientists have proved its ability to inhibit bacterial growth [11]. It has been investigated that there may exist marked differences in inhibitory activity of honey depending on its geographical origin and floral source [12].

The main objective of this study was to calculate total viable count, staphylococcal count, coliform count, isolation and identification of bacteria from un-pasteurized packed 
fruit juices to assess their quality and to determine antibacterial activity of honey samples against isolated bacteria.

\section{MATERIALS AND METHODS}

\section{Samples Collection}

Unpasteurized packed fruit juice samples $(n=60)$ were purchased from street vendors in Lahore city. The samples of fruit juices were examined in Bacteriology Laboratory, Department of Microbiology, University of Veterinary and Animal Sciences, Lahore.

\section{Isolation and Enumeration of Bacteria}

Un-pasteurized fruit juice samples procured from retail shops were analyzed for total viable counts (TVC), total staphylococcal counts (TSC), total coliform counts (TCC) and Salmonella-Shigella detection. Spread plate method was used for isolation and enumeration of bacteria from fruit juice samples. Ten-fold serial dilutions of homogenized suspension were prepared aseptically in Laminar flow by transferring $1 \mathrm{~mL}$ of each of fruit juice sample into $9 \mathrm{~mL}$ of sterile phosphate buffered saline tubes separately. Bacterial isolation and enumeration was done as described in earlier studies $[13,14]$ at selective media including nutrient agar for total viable counts [6], Staph 110 agar for staphylococcal counts and MacConkey agar for coliform counts. Inoculated plates were incubated at standard time-temperature combination [15]. After overnight incubation colonies were counted and colony forming units per milliliter $(\mathrm{CFU} / \mathrm{mL})$ were determined.

\section{Determination of Anti-bacterial Activity of Honey}

A total of five samples of various brands honey (AlNahal Natural Honey, Al-Shifa Natural Honey, Marhaba Honey, Islamic Shahad and Langnese Honey) were collected from market. The honey is produced by different companies on commercial scale and available in market. Some brands use wild bees while others produce honey using house bees. In subcontinent, at least four Apis species are found, i.e. Apis dorsata, Apis cerana, Apis florae and Apis andreniformis. Moreover, for large scale natural honey production the Apis Mellifera bees imported from Europe are widely used in honey farms. Samples were stored at $\left(23-25^{\circ} \mathrm{C}\right)$ in dark place. To determine antibacterial potential, honey samples were used undiluted and at 75, 50, and 25\% dilution. Antibacterial activity was tested for all bacterial isolates. Disc diffusion method [16] was used according to National Committee for Clinical Laboratory Standards. Filter paper discs were prepared and poured in $25 \mu \mathrm{l}$ of each honey dilution and Streptomycin (Positive control). The cultures of the test organism were streaked on Nutrient agar plates using a sterile cotton swab. The discs were placed on the plates and incubated at $37^{\circ} \mathrm{C}$ for $24 \mathrm{hrs}$. The diameters of zones of inhibition obtained were measured according to CLSI [17].

\section{Statistical Analysis}

Data obtained for bacterial load was tabulated using Microsoft Excel (MS Excel 2010, Microsoft Corporation). Statistical analyses were done using Statistical Package for the Social Sciences (SPSS version 16.0). Values were expressed as $\log 10 \mathrm{CFU} / \mathrm{ml}$. Appropriate test statistics one way ANOVA using Duncan Multiple Range (DMR) test were used.

\section{RESULTS}

Total Viable counts (TVC): Total viable count (TVC) is a measure of microbial quality of fruit juices. Presence of microbes in high numbers (TVC $>4 \log 10 \mathrm{CFU} / \mathrm{ml}$ ) is responsible for the spoilage of fruit juices (Gulf standards, (2000) and Codex standards, (2005). Mean TVCs in fruit juice samples vary non-significantly with the standard permissible counts $\left(\mathrm{p}^{<0.05}\right)$. Mean TVCs in all fruit juice samples $(6.80 \pm 1.91 \log 10 \mathrm{CFU} / \mathrm{ml})$ were greater than permissible limits (Table 1). In the present study, $66.66 \%$ of samples had TVC more than $4 \log 10 \mathrm{CFU} / \mathrm{ml}$ which indicates highly contaminated fruit juices.

Staphylococcal counts (SC): Microbial quality of fruit juices is related to staphylococcal counts. Presence of staphylococci in high numbers $(\mathrm{SC}>3 \log 10 \mathrm{CFU} / \mathrm{ml})$ is a health hazard as they cause spoilage of fruit juices and food borne diseases (Gulf standards, (2000) and Codex standards, (2005). Mean Staphylococcal counts in fruit juice samples vary non-significantly with the standard permissible counts $\left(p^{<0.05)}\right.$. Mean SC in all fruit juice samples $(5.45 \pm 1.06$ $\log 10 \mathrm{CFU} / \mathrm{ml}$ ) were greater than permissible limits (Table 1). In the present study, $51.66 \%$ of samples had SC more than $3 \log 10 \mathrm{CFU} / \mathrm{ml}$.

Coliform counts (CC): Coliforms are considered as indicators of quality. Presence of coliforms in high numbers $(\mathrm{CC}>2 \log 10 \mathrm{CFU} / \mathrm{ml})$ is health hazard causing spoilage of fruit juices and food borne diseases. Gulf standards, (2000) and Codex standards, (2005), Coliform counts in fruit juice samples vary non-significantly with the standard permissible counts $\left(p^{<0.05)}\right.$. Mean $C C$ in all fruit juice samples $(3.25 \pm 1.25 \log 10 \mathrm{CFU} / \mathrm{ml})$ were greater than permissible limits (Table 1). In the present study, $46.66 \%$ of samples had $\mathrm{CC}$ more than $2 \log 10 \mathrm{CFU} / \mathrm{ml}$.

\section{Prevalence of Bacteria in Fruit Juice Samples}

A total of $10(9.09 \%)$ Bacillus alvei, 22 (20\%) Bacillus polymyxa, 19 (17.27\%) Bacillus subtilis, 17 (15.45\%) Staphylococcus aureus, 9 (8.18\%) Pseudomonas aeruginosa, $14(12.72 \%)$ Klebsiella pneumonia, 6 (5.45\%) Enterobecter and $13(11.81 \%)$ Escherichia coli isolates were purified (Fig. 1).

\section{Antibacterial Activity of Honey}

Every dilution of each honey sample was tested against bacteria isolated from fruit juices such as Bacillus alvei, Bacillus subtilis, Bacillus polymyxa, Staphylococcus aureus, Klebsiella pneumonia, Pseudomonas aeruginosa, Enterobecter and Escherichia coli. All five different types of honey samples used in this study showed antibacterial activity against B. alvei, B. polymyxa, B. subtilis and S. aureus and no activity was found against $P$. aeruginosa, $K$. pneumonia, Enterobecter and E. coli. Islamic Shahad samples were found more effective as its lower dilutions showed antibacterial activity against most bacterial isolates and it might be due to purity of this brand of honey. Streptomycin was used as 
Table 1. Bacterial load from fruit juice samples as represented by mean $\log 10 \mathrm{CFU} / \mathrm{ml} \pm \mathrm{SD}$.

\begin{tabular}{|c|c|c|c|}
\hline & $\mathrm{n}^{\mathrm{a}}(\%)$ & $n^{a}(\%)$ & $\mathrm{n}^{\mathrm{a}}(\%)$ \\
\hline$>_{1}$ & $5(8.33)$ & $10(16.66)$ & $20(33.33)$ \\
\hline$>_{4}$ & $40(66.66)$ & - & - \\
\hline $\operatorname{Mean} \pm$ SD & $6.80 \pm 1.91$ & $5.45 \pm 1.06$ & $3.25 \pm 1.25$ \\
\hline
\end{tabular}

$\mathrm{n}^{\mathrm{a}}=$ Number of samples with $\mathrm{CFU} / \mathrm{ml}$ corresponding to the first column of same row

"-" means no samples having bacterial load in the range

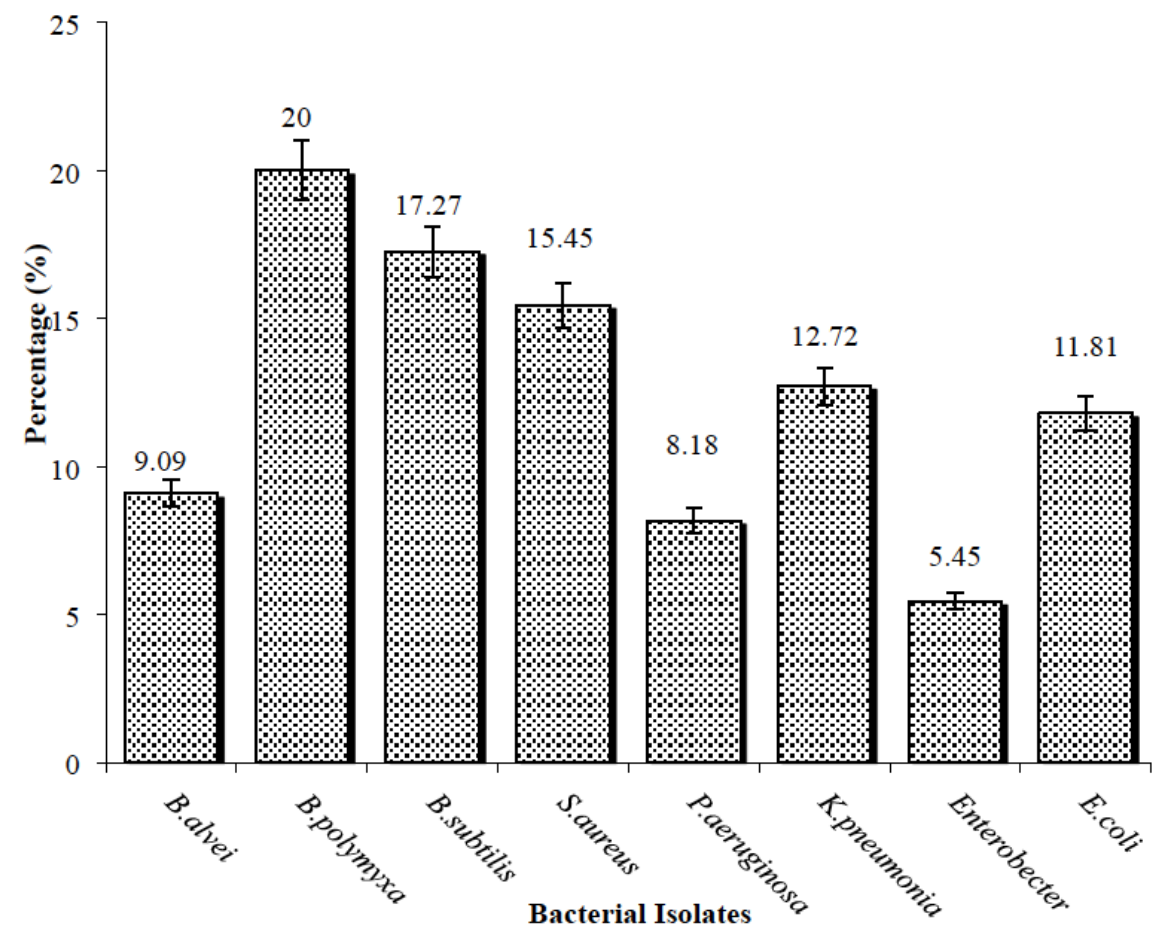

Fig. (1). Prevalence of bacterial isolates among unpasteurized fruit juices.

positive control and all the bacterial isolates showed zones of inhibition against this antibiotic (Table 2-6).

It was observed that $100 \%$ Al-Nahal Natural Honey showed maximum antibacterial activity against $B$. alvei, $B$. polymyxa, $B$. subtilis and $S$. aureus. $B$. polymyxa was susceptible against $25 \%$ dilution and $B$. subtilis and $S$. aureus were susceptible against $25 \%$ and $50 \%$ dilutions of honey. No activity was found against $P$. aeruginosa, $K$. pneumonia, Enterobecter and E. coli by any dilution of Al-Nahal Natural Honey (Table 2). Al-Shifa Natural Honey samples showed antibacterial activity against B. alvei, B. polymyxa, B. subtilis and $S$. aureus at $100 \%$ and $75 \%$ dilution. No activity was found against other bacteria (Table 3). It was observed that $100 \%$ Marhaba Honey showed antibacterial activity against B. alvei, B. polymyxa, B. subtilis and $S$. aureus and $75 \%$ dilution was active against B. polymyxa and $S$. aureus. No ac- tivity was found against other bacteria (Table 4). Islamic Shahad samples showed antibacterial activity against $B$. alvei, B. polymyxa, B. subtilis and $S$. aureus at $100 \%, 75 \%$ and $50 \%$ dilution. $25 \%$ dilution was active against $B$. polymyxa and $B$. subtilis. No activity was found against other bacteria (Table 5). It was observed that $100 \%$ and $75 \%$ Langese Honey showed antibacterial activity against $B$. alvei, B. polymyxa, B. subtilis and S. aureus and 50\% dilution was active against St. aureus. No activity was found against other bacteria (Table 6).

\section{DISCUSSION}

The bacterial count was low for some of the unpasteurized fruit juices and comparatively higher for some others. Higher levels of total viable counts (TVCs) in fruit juices were in accordance with the previous studies 
Table 2. Antibacterial activity of Al-Nahal Natural honey against bacterial isolates. Data are shown as mean zone of inhibition $\left(\mathbf{m m}^{2}\right) \pm$ SD.

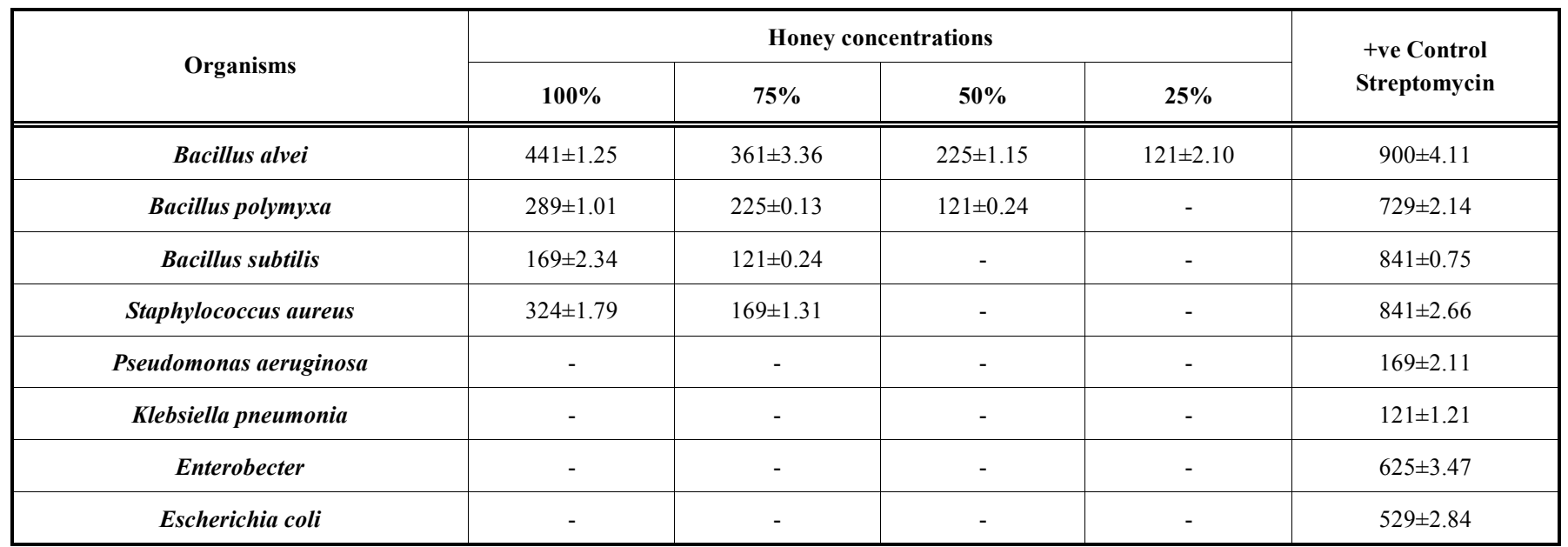

“+ve" means positive control, “-” means the absence of inhibition

Table 3. Antibacterial activity of Al-Shifa Natural honey against bacterial isolates. Data are shown as mean zone of inhibition $\left(\mathbf{m m}^{2}\right) \pm$ SD .

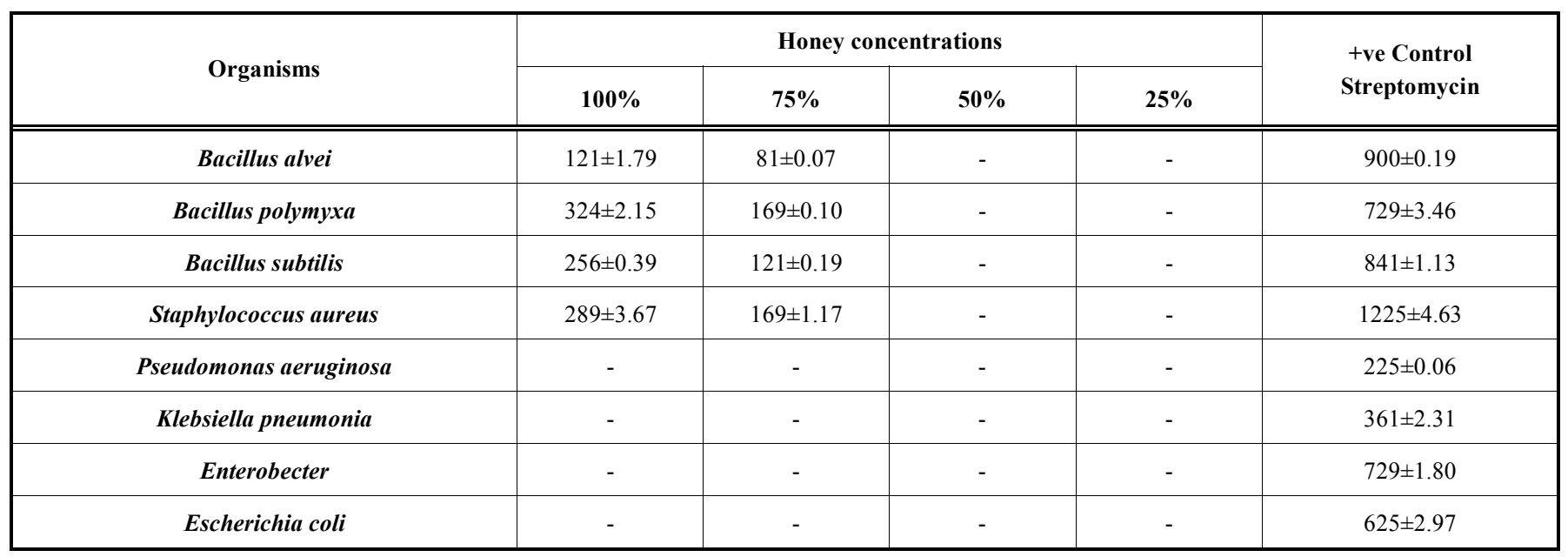

"+ve" means positive control, “-” means the absence of inhibition

Table 4. Antibacterial activity of Marhaba honey against bacterial isolates. Data are shown as mean zone of inhibition $\left(\mathrm{mm}^{2}\right) \pm \mathrm{SD}^{2}$

\begin{tabular}{|c|c|c|c|c|c|}
\hline Organisms & \multicolumn{4}{|c|}{ Honey concentrations } & $\begin{array}{l}\text { +ve Control } \\
\text { Streptomycin }\end{array}$ \\
\hline Bacillus polymyxa & $225 \pm 0.04$ & $121 \pm 2.22$ & - & - & $441 \pm 1.33$ \\
\hline Bacillus subtilis & $121 \pm 1.01$ & - & - & - & $529 \pm 1.41$ \\
\hline Pseudomonas aeruginosa & - & - & - & - & $169 \pm 0.48$ \\
\hline Klebsiella pneumonia & - & - & - & - & $361 \pm 0.07$ \\
\hline Enterobecter & - & - & - & - & $729 \pm 1.11$ \\
\hline
\end{tabular}

"+ve" means positive control, "-" means the absence of inhibition 
Table 5. Antibacterial activity of Islamic Shahad against bacterial isolates. Data are shown as mean zone of inhibition $\left(\mathrm{mm}^{2}\right) \pm \mathrm{SD}^{2}$

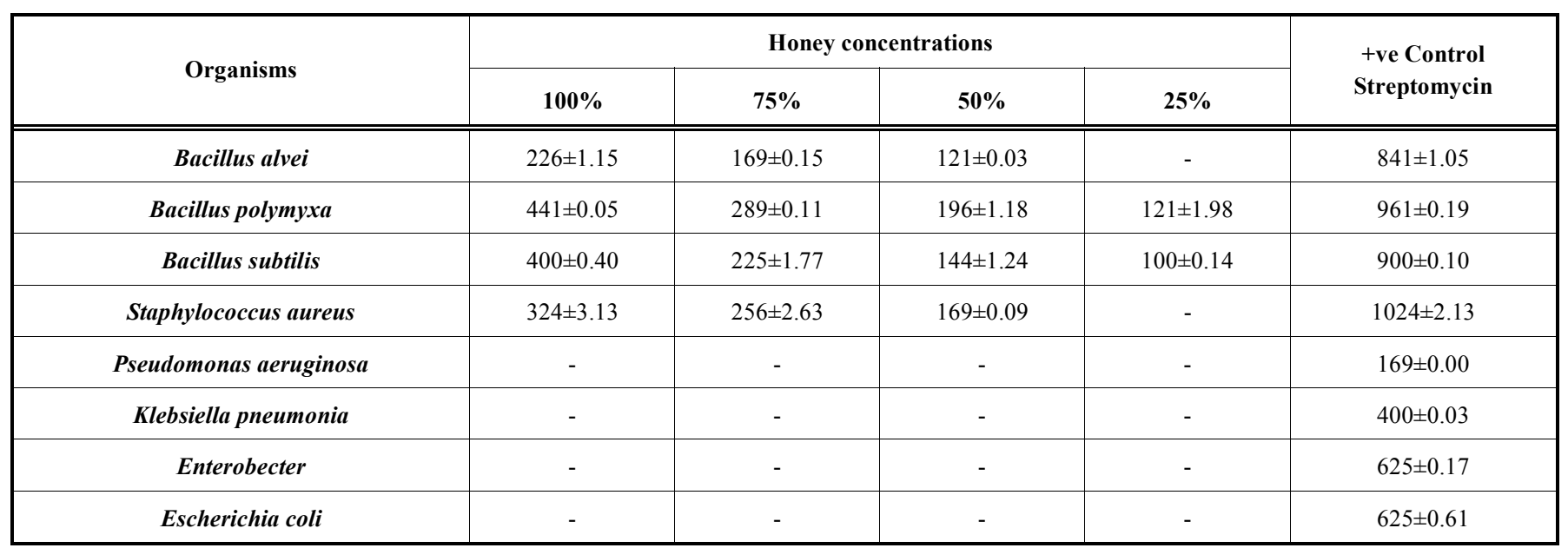

"+ve" means positive control, "-_" means the absence of inhibition

Table 6. Antibacterial activity of Langnese honey against bacterial isolates. Data are shown as mean zone of inhibition $\left(\mathrm{mm}^{2}\right) \pm \mathrm{SD}^{2}$

\begin{tabular}{|c|c|c|c|c|c|}
\hline Organisms & \multicolumn{4}{|c|}{ Honey concentrations } & $\begin{array}{l}\text { +ve Control } \\
\text { Streptomycin }\end{array}$ \\
\hline Bacillus polymyxa & $289 \pm 1.97$ & $169 \pm 1.02$ & - & - & $784 \pm 1.86$ \\
\hline Bacillus subtilis & $676 \pm 3.22$ & $121 \pm 1.25$ & - & - & $676 \pm 0.21$ \\
\hline Pseudomonas aeruginosa & - & - & - & - & $121 \pm 0.32$ \\
\hline Klebsiella pneumonia & - & - & - & - & $361 \pm 0.68$ \\
\hline Enterobecter & - & - & - & - & $529 \pm 1.02$ \\
\hline Escherichia coli & - & - & - & - & $676 \pm 0.11$ \\
\hline
\end{tabular}

"+ve" means positive control, "-_" means the absence of inhibition

[5, 18-21]. The relatively higher bacterial counts were due to poor hygienic conditions and cause food spoilage and food borne illnesses. These findings about the bacterial load were against the findings of Tasnim et al. [22], who reported the bacterial counts of fruit juices within the standard limits.

Higher levels of staphylococcal counts (SCs) in fruit juices were in accordance with the previous studies [21, 23], who have also reported significant levels of staphylococcal counts in fruit juices. Higher levels of staphylococcal counts (CCs) in fruit juices were in accordance with the previous studies of Rashed et al. [21], who reported the coliform count of $3.6 \times 10^{4} \mathrm{CFU} / \mathrm{ml}$ in fruit juices. These results suggested unsatisfactory hygienic practices during the preparation of these beverages.

The results are according to previous findings $[14,18$, 23]. It suggests that although most of the microbes do not survive low $\mathrm{pH}$ of juices and processing methods also kill most of the microbes but certain spores of Bacillus spp. survive and pose a serious threat to the consumers. It was suggested that quality of fruit juices should be monitored on regular basis to avoid any future outbreaks [19].
The present study revealed antibacterial activity of different honey samples against gram positive bacteria at various concentrations and no activity was found against gram negative bacteria. Various studies had showed antibacterial activity of honey samples against various bacteria [24-26], which indicated that honey can be used as an alternative to antibiotics to treat various infections.

In the present study, honey samples showed antibacterial activity in undiluted, 75 and $50 \%$ but start to decrease with decreasing the dilution percentage particularly against $B$. alvei, $B$. polymyxa, B. subtilis and $S$. aureus. The range of antimicrobial activity of honey has been reported from concentrations of $3 \%$ to $50 \%$ and higher according to many investigators $[12,27]$.

Antibacterial activity is influenced by the concentration of honey [24], the higher concentrations provoke its usefulness as an antibacterial agent. The antimicrobial activity of honey has been shown to range from concentrations $<3 \%$ to $50 \%$ and higher by French et al. [28]. It has been shown that the bactericidal effect of honey is influenced by its concentration and the nature of the bacteria [29]. 
Honey has very good inhibitory potential against E. coli, Shigella and Salmonella [30]. Various factors are responsible for variation of antimicrobial potency among the different honeys that include its seasonal, geographical and botanical source as well as harvesting, processing and storage conditions [31].

Honey contains $80 \%$ sugars, mainly glucose and fructose and some sucrose and maltose, and less than $18 \%$ water. Osmotic stress caused by high concentration of sugars and low moisture content causes prevents spoilage of honey by microorganisms. At higher dilutions, compounds other than sugar are responsible for the antibacterial activity. In the $1960 \mathrm{~s}, \mathrm{H}_{2} \mathrm{O}_{2}$ was identified as a major antibacterial compound in honey which is produced by the enzyme glucose oxidase from glucose [32]. However, various honeys have shown antibacterial activity due to nonperoxide components. Recently, methylglyoxal and bee defensin- 1 have been identified in honey which are antibacterial compounds. The contribution of the low pH (generally between 3.2 and 4.5) for the antibacterial activity of honey has been shown [33]. In addition, there are clear indications for the presence of additional honey antibacterial compounds of which the identity remains to be elucidated.

All the fruit juices sold on roadside were found highly contaminated with pathogenic bacteria. Lack of pasteurization is one of the major factors responsible for contamination of fruit juices. These organisms should be tested at specific control points to attain a better quality control. The best methods for prevention of contamination include constant surveillance and good manufacturing practice [34]. Therefore, it is suggested that these juices should be monitored periodically in food laboratories for quality and human consumption.

As an alternative honey can be mixed with the fruit juices as flavor or as sweetener so that antibacterial properties of honey may preserve the juices from contaminants. Some honey milk products such as pasteurized and homogenized sweetened with honey for long time storage e.g. yoghourt with honey is found in industrial sector [35]. The use of honey in the industrial non-alcoholic beverage industry is relatively recent and expanded in 1990. Over 40 new honey drinks were introduced in Japan and in many fruit juices; honey is added as flavoring and sweetener. In apple juice, it is also used to classify fruit juice [36].

\section{CONCLUSION}

In the light of prevalent microbiological standards for fruit juices, it is suggested that un-pasteurized packed fruit juices are the potential sources for common food borne diseases in the region. Microbial resistance against antibiotics is another emerging food safety issue and may provoke the health related issues in Pakistan. A precise and well defined monitoring and surveillance system needs to be implemented on urgent grounds to address the food safety in Pakistan. The study showed that certain organisms are sensitive to honey and it could be used as an alternative to antibiotics against certain bacteria. Therefore, there is need to investigate possible use of honey for therapies of bacterial infections by characterizing the active components of honey extracts.

\section{CONFLICT OF INTEREST}

The authors confirm that this article content has no conflict of interest.

\section{ACKNOWLEDGEMENTS}

The authors are grateful to Professor Aftab Ahmad Anjum, Department of Microbiology, University of Veterinary and Animal Sciences, Lahore for providing materials to carry out this research.

\section{REFERENCES}

[1] Codex Stan. Codex general standard for fruit juices and nectars. Codex Stan 2005; 247: 1-19.www.codexalimentarius.net/

[2] Fawole MO, Osho BA. Laboratory manual of Microbiology. Spectrum Books LMD 2002; pp. 6-45.

[3] Deanna MM, Jeffrey SB. Acid-alkaline balance: role in chronic disease and detoxification. Alternat Ther 2007; 13: 62-5.

[4] Suaad SA, Eman AHA. Microbial growth and chemical analysis of mineral contents in bottled fruit juices and drinks in Riyadh, Saudi Arabia. Res J Microbiol 2008; 3: 319-25.

[5] Bagde NI, Tumane PM. Studies on microbial flora of fruit juices and cold drinks. Asiatic J Biotech Resour 2011; 2: 454-60.

[6] Akhtar S, Riaz M, Ismail T, et al. Microbiological Safety of street vended fresh fruit juices, drinks and conventional blends in MultanPakistan. Pak J Agri Sci 2013; 50: 255-60.

[7] Mahale DP, Khade RG, Vaidya VK. Microbiological analysis of street vended fruit juices from Mumbai city, India. Int $\mathbf{J}$ Food Safety $2008 ; 10: 31-4$.

[8] Nicolas B, Razack BA, Yollande I, et al. Street-vended foods improvement: contamination mechanisms and application of food safety objective strategy: critical review. Pak J Nutr 2007; 6: 1-10.

[9] Ukwo SP, Ndaeyo NU, Udoh EJ. Microbiological quality and safety evaluation of fresh juices and edible ice sold in uyo metropolis, south-south, Nigeria. Int J Food Saf 2011; 13: 374-8.

[10] Rahman MM, Richardson A, Sofian-Azirun M. Antibacterial activity of propolis and honey against Staphylococcus aureus and Escherichia coli. Afr J Microbiol Res 2010; 4: 1872-8.

[11] Lotfi A. Use of honey as a medicinal product in wound dressing (human and animal studies): a review. Res J Biol Sci 2008; 3: 13640 .

[12] Lusby PE, Coombes AL, Wilkinson JM. Bactericidal activity of different honeys against pathogenic bacteria. Arch Med Res 2005; 36: 464-7.

[13] Prescott LM, Harley JP, Kleen DA. Microbiology, $5^{\text {th }}$ ed. New York: McGraw Hill 2002; pp. 965-72.

[14] Ghenghesh KS, Belhaj K, El-Amin WB, et al. Microbiological quality of fruit juices sold in Tripoli-Libya. Food Control 2005; 16 : 855-8.

[15] USFDA. Bacteriological analytical manual online.2001.Available at: http://www.fda.gov/Food/ScienceResearch/LaboratoryMethods/ BacteriologicalAnalytical ManualBAM/default.htm

[16] Bauer AW, Kirby WWM. Antibiotic susceptibility tests by standard sigle disc method. Am J Clin Pathol 1966; 45: 493-6.

[17] CLSI. Performance standards for antimicrobial susceptibility testing. Clinical and Laboratory Standards Institute. $16^{\text {th }}$ Informational Supplement M100-S16. Wayne, PA 2006.

[18] Rahman T, Hasan S, Noor R. An assessment of microbiological quality of some commercially packed and fresh fruit juices available in dhaka city: a comprehensive study. Stanford J Microbiol 2011; 1: 13-8.

[19] Lewis JE, Thompson P, Rao B, et al. Human bacteria in street vended fruit juices in India. Int J Food Saf 2006; 8: 35-8.

[20] Durgesh PM, Ranjana GK, Varsha KV. Microbiological analysis of street vended fruit juices from Mumbai city, India. Int J Food Safety $2008 ; 10: 31-4$.

[21] Rashed MN, Aftab U, Azizul MH, et al. Microbiological study of vender and packed fruit juices locally available in Dhaka city, Bangladesh. Int Food Res J 2013; 20: 1011-5.

[22] Tasnim F, Anwar HM, Nusrath S, et al. Quality assessment of industrially processed fruit juices vailable in Dhaka city, Bangladesh. Mal J Nutr 2010; 16: 431-8. 
[23] Ahmed MSU, Nasreen T, Feroza B, et al. Microbiological quality of local market vended freshly squeezed fruit juices in Dhaka city, Bangladesh. Bangladesh J Sci Ind Res 2009; 44: 421-4.

[24] Badawy OFH, Shafii SSA, Tharwat EE, et al. Antibacterial activity of bee honey and its therapeutic usefulness against Escherichia coli O157:H7 and Salmonella typhimurium infection. Rev Sci Technol Int Epiz 2004; 23: 1011-122.

[25] Gomashe AV, Narad MV, Gulhane P. In vitro Assessment of the antimicrobial potential of honey against enteric pathogens. Int Res J Sci Eng 2014; 2: 153-7.

[26] Hamouda HM, Marzouk DS. Antibacterial activity of egyptian honey from different sources. Int J Microbiol Res 2011; 2: 149-55.

[27] Wilkinson JM, Cavanagh HM. Antibacterial activity of 13 honeys against Escherichia coli and Pseudomonas aeruginosa. J Med Food 2005; 8: 100-3.

[28] French VM, Cooper RA, Molan PC. The antibacterial activity of honey against coagulase-negative staphylococci. J Antimicrob Chemother 2005; 56: 228-31.

[29] Basualdo C, Sgroy V, Finola MS, et al. Comparison of the antibacterial activity of honey from different provenance against bacteria usually isolated from skin wounds. Vet Microbiol 2007; 124: 37581.

[30] Zumla A, Lulat A. Honey-a remedy rediscovered. J R Soc Med 1989; 82: 384-5.

[31] Molan PC, Cooper RA. Honey and sugar as a dressing for wounds and ulcers. Trop Doct 2000; 30: 249-50.

[32] Molan PC. The antibacterial activity of honey. The nature of the antibacterial activity. Bee World 1992; 73: 5-28.

[33] Kwakman PHS, Te Velde AA, de Boer L, et al. How honey kills bacteria. FASEB J 2010; 24: 2576-82.

[34] Juhaniakova L, Kacaniova M, Petrova J, et al. Microbiological quality of confectionary products. J Micro Biotech Food Sci 2013; 2: $1244-51$.

[35] Ebisu T, Maeda N, Matsubara H, et al. Honey powder. Composition as additives for foods and Pharmaceuticals. Japanese Patient Number 1988; 63: 157-943.

[36] Spanish Dairy Corporation. Preparation of yoghurt with honey. International Symposium on Apitherapy, Madrial 1975; pp. 55-6.

Received: December 23, 2014

Revised: April 27, 2015

Accepted: May 30, 2015

(C) Iqbal et al.; Licensee Bentham Open.

This is an open access article licensed under the terms of the Creative Commons Attribution Non-Commercial License (http://creativecommons.org/licenses/by-nc/3.0/) which permits unrestricted, non-commercial use, distribution and reproduction in any medium, provided the work is properly cited. 